\title{
Molecular analysis of skeletal tuberculosis in an ancient Egyptian population
}

\author{
ALBERT ZINK*, CHRISTIAN J. HAAS*†, UDO REISCHL + ULRIKE SZEIMIES§ and \\ ANDREAS G. NERLICH* \\ * Department of Pathology, Ludwig-Maximillians-Universität, D-80337 München, †Department of Pathology, \\ Friedrich-Alexander Universität Erlangen-Nürnberg, D-91054, \$Institute of Medical Microbiology and Hygiene, \\ University, D-93053 Regensburg and §Department of Diagnostic Radiology, Ludwig-Maximilians-Universität, D- \\ 80336 München, Germany
}

A paleomicrobiological study was performed on 37 skeletal tissue specimens from cadavers in the necropolis of Thebes-West, Upper Egypt, (2120-500 BC) and four from the necropolis of Abydos (3000 BC). The subjects had typical macromorphological evidence of osseous tuberculosis $(n=3)$, morphological alterations that were not specific, but probably resulted from tuberculosis $(n=17)$, or were without morphological osseous changes $(n=21)$. DNA was extracted from these bone samples and amplified by PCR with a primer pair that recognised the Mycobacterium tuberculosis complex insertion sequence IS6110. To confirm specificity of the analysis, the amplification products of several samples were subjected to restriction enzyme digestion, or direct sequencing, or both. In 30 of the 41 cases analysed, ancient DNA was demonstrated by amplification by the presence of the human $\beta$-actin or the amelogenin gene and nine of these cases were positive for $M$. tuberculosis DNA. The results were confirmed by restriction endonuclease digestion and sequencing. A positive result for $M$. tuberculosis DNA was seen in two of the three cases with typical morphological signs of tuberculosis and amplifiable DNA, in five of 13 non-specific, but probable cases (including two cases from $c$. $3000 \mathrm{BC}$ ), but also in two of 14 cases without pathological bone changes. These observations confirm that tuberculosis may be diagnosed unequivocally in skeletal material from ancient Egypt, even dating back to $c .3000$ BC. As a positive molecular reaction was observed in most of the typical cases of skeletal tuberculosis, in about one-third of non-specific, but probable tuberculous osseous changes and, surprisingly, in about one-seventh of unremarkable samples, this suggests that infection with $M$. tuberculosis was relatively frequent in ancient Egypt.

\section{Introduction}

The molecular identification of bacterial DNA, such as from Mycobacterium tuberculosis, has recently been shown to provide an increasingly useful tool for the detection of infectious diseases in ancient populations [1-10]. Most of those studies have been performed on bone tissue of isolated cases or small series of samples, mostly with typical osseous alterations suggestive of tuberculosis. In very few instances, mycobacterial DNA was also detected in mummified internal organs from Egyptian and South American mummies [2,5]. However, no data are available yet about the frequency of

Received 14 March 2000; revised version received 9 Sept. 2000; accepted 15 Sept. 2000.

Corresponding author: Professor A. G. Nerlich (e-mail: Andreas.Nerlich@1rz.uni-muenchen.de). those infectious diseases in previous times. The estimation of this rate offers a highly interesting insight into ancient living conditions and provides significant data on the possible role of those infectious diseases in previous populations.

Tuberculous bone infection results from haematogenous dissemination, mostly of pulmonary or intestinal tuberculosis. However, data on present day populations suggest that this is a rather rare event, indicating that $<10 \%$ of patients with chronic tuberculosis suffer from osseous involvement [11]. Thus, the identification of only a few cases with bone tuberculosis may indicate a much more widespread epidemiological occurrence of the disease.

Earlier studies identified DNA of the M. tuberculosis complex in skeletal and soft tissue material from 
several mummified individuals from ancient Egypt $[5,12]$ buried in the necropolis of Thebes-West and dating from one of the most prosperous eras of Egyptian history (the so-called 'New Kingdom', $c$. 1550-1000 BC). These preliminary studies suggested that $M$. tuberculosis DNA can be identified unambiguously in the ancient Egyptian material, allowing an unequivocal diagnosis of tuberculous infection. This is particularly important in order to rule out other diagnoses that may mimic osseous tuberculosis, e.g., sequelae of trauma or other infectious diseases, such as brucellosis. Moreover, as yet only one report has prompted the search for $M$. tuberculosis in ancient bone samples without pathological alterations, providing evidence that $M$. tuberculosis DNA may even be identified in morphologically normal bones [6].

In this study, an extensive molecular analysis of the frequency of $M$. tuberculosis (as evidenced by molecular identification of gene segments of the $M$. tuberculosis complex) in osseous tissue samples from various individuals, both with and without typical lesions suggestive of tuberculosis, was performed. The intention was to obtain insight into the rate of mycobacterial infections in a series of tissue samples to provide an initial basis for the estimation of the frequency of tuberculosis in that population.

\section{Materials and methods}

\section{Bone material}

The study material was taken from the necropolis of Thebes-West where extensive anthropological and paleopathological examinations were performed on human remains, mainly from several 'tombs of the nobles'. These tombs were built during the Middle Kingdom (c. 2050-1650 BC) and New Kingdom (c. 1550-1080 BC) and used until the Late Period (c.
$500 \mathrm{BC})$. During the investigations, it was possible to identify the remains of at least 566 individuals, most of which had been significantly destroyed by extensive preceding grave robberies and mostly skeletonised. Despite these effects, the osseous material was in excellent condition due the lack of water contact at the hill sites and to the stable temperatures in the burial shafts. Another four bone samples were obtained from the necropolis of Abydos, Upper Egypt, which had been used in predynastic up to early dynastic times ( $c$. $3050-2650 \mathrm{BC}$ ). Here again, the material was skeletonised, but very well preserved.

Bone samples from 41 cases were used, and were classified as showing typical morphological alterations suggestive of tuberculosis, as samples with non-specific bone changes, where tuberculosis was not suggested, or a third group of samples without any morphological evidence of bone pathology. On the basis of this classification, three cases belonged to group 1 (morphology suggestive of tuberculosis) and, 17 cases had minor and limited alterations (group 2). Finally, as a control group, 21 samples from different individuals did not reveal any morphological pathological lesion (group 3). The basic archaeological and anthropological data available on the material are summarised in Tables 1 and 2. Before molecular analysis, several samples were subjected to radiological analysis including computed tomography, allowing for a more detailed examination of the intra-bone lesions. The differential diagnoses of the observed lesions were performed according to basic paleopathological and radiological studies $[13,14]$.

\section{DNA extraction}

To eliminate contamination, the bones were first cleaned with sodium hypochlorite $0.5 \%$ solution and then the outer surface was removed mechanically.

Table 1. Description and molecular findings of the study population - samples with macro-morphological alterations

\begin{tabular}{|c|c|c|c|c|c|c|}
\hline Case no. & Dating & $\begin{array}{l}\text { Age } \\
\text { (years) }\end{array}$ & Sex & Macro-morphology & $\beta$-Actin & IS 6110 \\
\hline TT84-70 & New Kingdom & $20-30$ & M & L4/L5, advanced stage lumbar vertebral tuberculosis & + & + \\
\hline TT85-2-51 & New Kingdom & Adult & $?$ & Fusion L4-S1, lumbo-sacral tuberculosis & + & + \\
\hline DAN 33 K93.11 & New Kingdom & Adult & M & Collapsed/fused T12/L1, tuberculous spondylitis & + & - \\
\hline TT84-4 & New Kingdom & Adult & $?$ & Destruction L3, probable tuberculosis spondylitis & + & - \\
\hline TT85-2-21 & New Kingdom & Adult & $?$ & Fusion $\mathrm{H} 7, \mathrm{~B} 12$; probable tuberculosis spondylitis & + & - \\
\hline TT95-28 & New Kingdom & Adult & $?$ & Periostitis rib; probable pulmonary tuberculosis & + & - \\
\hline TT95-34 & New Kingdom & Adult & $?$ & Periostitis clavicle; probable osseous tuberculosis & + & - \\
\hline TT95-35 & New Kingdom & Adult & M & Periostitis rib; probable pulmonary tuberculosis & + & - \\
\hline TT95-41 & New Kingdom & Adult & ? & Fusion $\mathrm{H} 6 / \mathrm{H} 5$; probable tuberculous spondylitis & + & - \\
\hline TT95-164 & New Kingdom & Adult & ? & Slight periostitis rib; probable pulmonary tuberculosis & - & - \\
\hline TT183-29 & New Kingdom & Adult & $?$ & Destruction L2; probable tuberculous spondylitis & + & + \\
\hline TT196-M163 & Middle Kingdom & Adult & M & Deformation L3; probable tuberculous spondylitis & + & + \\
\hline TT453-15 & New Kingdom & Adult & $?$ & Fusion T8-L2; DISH/probable tuberculous spondylitis & + & + \\
\hline DAN O K93.11 & New Kingdom & Adult & $?$ & Osteolysis B9; probable tuberculous spondylitis & + & - \\
\hline DAN-31-K94.1 & New Kingdom & Juvenile & M & Osteolysis L1; probable tuberculous spondylitis & - & - \\
\hline DAN 46 K95.1 & Middle Kingdom & Adult & $?$ & Deformation T12; probable tuberculous spondylitis & - & - \\
\hline DAN-106-K94.1 & New Kingdom & Adult & $?$ & Deformation L3; probable tuberculous spondylitis & - & - \\
\hline DAN-M7-K93.11 & New Kingdom & $30-50$ & $\mathrm{~F}$ & Osteolysis L4; probable tuberculous spondylitis & - & - \\
\hline U 559 Abydos & Predynastic & $20-40$ & $\mathrm{~F}$ & Osteolysis L2; probable tuberculous spondylitis & + & + \\
\hline Q-W5 & Early Dynastic & Adult & $?$ & Osteolysis T6; probable tuberculous spondylitis & + & + \\
\hline
\end{tabular}


Table 2. Description and molecular findings of the study population - samples without macro-morphological evidence of tuberculosis

\begin{tabular}{|c|c|c|c|c|c|c|}
\hline Case no. & Dating & Age (years) & Sex & Bone sample & $\beta$-Actin & IS 6110 \\
\hline ТT95-13 & New Kingdom & $40-60$ & $\mathrm{~F}$ & Tarsal bone & + & - \\
\hline TT95-44 & New Kingdom & Adult & $?$ & Tarsal bone & + & - \\
\hline DAN 74 K93.11 & New Kingdom & Adult & M & Skull bones & + & + \\
\hline DAN 75 K93.11 & New Kingdom & Adult & $?$ & Skull bones & - & - \\
\hline DAN C K93.11 & New Kingdom & $20-40$ & $\mathrm{M}$ & Temporal bone & - & - \\
\hline DAN E K93.11 & New Kingdom & $20-40$ & $\mathrm{~F}$ & Temporal bone & - & - \\
\hline DAN 3 K93.11 & New Kingdom & $20-30$ & M & Temporal bone & + & + \\
\hline DAN 6 K93.11 & New Kingdom & $40-60$ & M & Temporal bone & + & - \\
\hline DAN PC3 K95.1 & Middle Kingdom & $20-30$ & $\mathrm{~F}$ & Temporal bone & + & - \\
\hline DAN S3 K95.1 & Middle Kingdom & $20-30$ & M & Temporal bone & + & - \\
\hline TT183-S3 & New Kingdom & $20-30$ & $\mathrm{~F}$ & Temporal bone & + & - \\
\hline TT183-S4 & New Kingdom & $20-30$ & M & Temporal bone & - & - \\
\hline TT183-T45b & New Kingdom & $40-60$ & M & Temporal bone & + & - \\
\hline TT183-KW & New Kingdom & $6-8$ & $?$ & Temporal bone & - & - \\
\hline TT196-Ma & Middle Kingdom & Adult & $?$ & Lumbar vertebra & + & - \\
\hline TT196-Mb & Middle Kingdom & Adult & $?$ & Lumbar vertebra & + & - \\
\hline DAN-22-K94.1 & New Kingdom & Adult & $?$ & Lumbar vertebra & + & - \\
\hline DAN-M1-K93.11 & New Kingdom & $30-50$ & M & Lumbar vertebra & - & - \\
\hline DAN-M2-K93.11 & New Kingdom & $30-40$ & M & Thoracic vertebra & - & - \\
\hline T-NH-A1 & Early Dynastic & Adult & $?$ & Lumbar vertebra & - & - \\
\hline B16-4a N & Early Dynastic & Adult & $?$ & Thoracic vertebra & - & - \\
\hline
\end{tabular}

Samples were taken from the inner part of the bones and pulverised with a mixer mill (Retsch MM200, Haan, Germany). A sample of the pulverised material $(1 \mathrm{~g})$ was incubated with $2 \mathrm{ml}$ of $0.5 \mathrm{M}$ EDTA solution containing proteinase $\mathrm{K} 0.25 \mathrm{mg} / \mathrm{ml}$ at room temperature for 2 days on a rotatory mixer [15]. Following centrifugation for $15 \mathrm{~min}$ at $3000 \mathrm{~g}, 0.5 \mathrm{ml}$ of the supernate was removed and $1 \mathrm{ml}$ of guanidine isothiocyanate solution and diatomaceous earth [16] were added. After incubation on a rotatory mixer for another $2 \mathrm{~h}$, the diatomaceous earth was pelleted by centrifugation and washed twice with ethanol $70 \%$ and once with acetone. The DNA was eluted with $80 \mu \mathrm{l}$ of sterile water. Finally, another washing and concentration step was performed with Microcon-30 filters (Millipore, Bedford, MA, USA) and the final DNA solution was diluted to $20 \mu \mathrm{l}$ with sterile water to give a final concentration of $20-40 \mu \mathrm{g} / \mathrm{ml}$.

\section{Precautions to prevent contamination}

Several precautions were taken to avoid contamination during the extraction procedure and in the PCR reactions. The extraction, PCR and post-PCR analyses were all conducted in separate rooms of the building, where no studies of modern mycobacterial or human DNA have ever been performed. All reagents were purchased as DNAase and RNAase-free molecular biology grade chemical or autoclaved when appropriate. No positive PCR controls were used. Disposable gloves were worn during all different procedures and changed frequently. Sterile aerosol protection filter tips were exclusively used (Biozym, Oldendorf Germany) to avoid cross-contamination. Two extraction blanks were always included in the same procedure and an additional PCR blank was included in each PCR reaction, containing no DNA template. As a further control, the test for amelogenin and SRY was compared to the anthropological data, as the excavation and analysis crew consisted exclusively of males (in Egypt and in Munich). Finally, c. 50\% of the specimens were analysed in two different institutions (Munich and Regensburg) using the same analysis procedure in parallel. Virtually the same results were obtained in both laboratories.

\section{Amplification of mycobacterial DNA}

A primer pair targeting a 123-bp segment of the repetitive sequence IS6110 of $M$. tuberculosis complex which covers $M$. tuberculosis, M. bovis, M. microti, $M$. africanum and $M$. simiae, was used for the specific amplification of mycobacterial DNA [17]. The PCR reaction mix contained $10 \mathrm{mM}$ Tris- $\mathrm{HCl}$ (pH 8.3), $50 \mathrm{mM} \mathrm{KCl}, 1.5 \mathrm{mM} \mathrm{MgCI}, 200 \mu \mathrm{M}$ of each deoxynucleotide trisphosphate (Amersham Pharmacia, Uppsala, Sweden), $1 \mu \mathrm{M}$ of each primer, $0.025 \mathrm{U} / \mu \mathrm{l}$ AmpliTaq Gold (PE Biosystems, Foster City, CA, USA) and $0.5 \mu 1$ of extracted DNA to a final volume of $20 \mu \mathrm{l}$. PCR conditions were as follows: $10 \mathrm{~min}$ at $95^{\circ} \mathrm{C}$ followed by 45 cycles of $94^{\circ} \mathrm{C}$ for $1 \mathrm{~min}, 66^{\circ} \mathrm{C}$ for $1 \mathrm{~min}$ and $72^{\circ} \mathrm{C}$ for $1 \mathrm{~min}$. After the final cycle another $8 \mathrm{~min}$ at $72^{\circ} \mathrm{C}$ were added.

\section{Amplification of human DNA}

To test whether amplifiable DNA was present in the samples and to ascertain that the PCR was not inhibited, a 202-bp segment of the human $\beta$-actin gene was amplified in parallel [18]. The PCR mixture was prepared as described above. The following amplification protocol was used: $10 \mathrm{~min}$ at $95^{\circ} \mathrm{C}, 45$ cycles of $94^{\circ} \mathrm{C}$ for $1 \mathrm{~min}, 60^{\circ} \mathrm{C}$, for $3 \mathrm{~min}$ and $72^{\circ} \mathrm{C}$ for $3 \mathrm{~min}$, and final extension at $72^{\circ} \mathrm{C}$ for $8 \mathrm{~min}$. 
For the molecular sex identification a segment of the amelogenin gene and the SRY gene were amplified, which are located on the human sex chromosomes. A 93-bp fragment was amplified from the SRY gene, which is located solely on the Y-chromosome [19]. The amplification product of the amelogenin gene is a 112bp fragment from the Y-chromosome and a 106-bp fragment of the X-chromosome [20]. Therefore, males show two PCR products and females give a single amplification product. The amplification protocol for the amelogenin gene was as follows: $10 \mathrm{~min}$ at $95^{\circ} \mathrm{C}$, 45 cycles of $94^{\circ} \mathrm{C}$ for $1 \mathrm{~min}, 60^{\circ} \mathrm{C}$ for $2 \mathrm{~min}, 72^{\circ} \mathrm{C}$ for $2 \mathrm{~min}$, and final extension at $72^{\circ} \mathrm{C}$ for $8 \mathrm{~min}$. The SRY PCR was performed with the same conditions, except that an annealing temperature of $58^{\circ} \mathrm{C}$ was used.

\section{Restriction endonuclease digestion}

In several cases, the 123-bp PCR product of IS6110 was digested with Hae III [21]. For the digestion, $8 \mu \mathrm{l}$ of the PCR product were incubated with $10 \mathrm{U}$ of Hae III (Roche Diagnostics, Mannheim, Germany) for $2 \mathrm{~h}$ at $37^{\circ} \mathrm{C}$. This resulted in a 94-bp and a 29-bp fragment.

\section{Detection of PCR and digestion products}

The PCR products were electrophoresed on an agarose $4 \%$ gel and visualised on a UV screen after staining with ethidium bromide. PCR products of the amelogenin gene amplification were also separated on a polyacrylamide $15 \%$ gel and visualised by silver staining.

\section{Sequence analysis of PCR products}

The nucleotide sequences of the PCR products were determined by direct sequencing. After electrophoresis on a low-melting-point agarose $4 \%$ gel, the respective fragment of the PCR reaction was eluted with a purification kit (Freeze'n Squeeze, BioRad, Hercules, CA, USA). Cycle sequencing was performed on the eluted DNA with a dye terminator cycle sequencing kit (PE Biosystems). Automatic sequencing was performed on an ABI PRISM 310 Genetic Analyzer (PE Biosystems).

\section{Results}

\section{Morphological findings}

The paleopathological investigation of the 41 cases revealed three individuals with the typical morphological alterations of skeletal tuberculosis. In a further 17 cases, non-specific bone changes were seen, providing evidence for a pathological process but without presenting the typical features of tuberculosis. Finally, the study analysed 21 samples from individuals with normal morphology. The cases are discussed briefly below.
Cases typical of tuberculosis. The study material contained three cases presenting with morphological changes of typical tuberculosis. The first case (identification number TT-84-70) has already been described extensively in a previous report [5]. This was the mummy torso of a young adult male with head and both arms missing. The chest wall was intact and there were no signs of evisceration. According to pubic morphology his age is suggested to be $<35$ years. During autopsy, signs of severe spondylitis of the two lowest lumbar vertebral bodies were detected, with severe lipping and partial destruction of the anterior vertebral bodies (Fig. 1a. b). The previously unopened chest contained residues of both lungs, the right one presenting with extensive pleural adhesions of the lung to the diaphragm and the chest wall, strongly suggesting chronic pleuritis. The combination of the pulmonary and osseous lesions strongly supported the diagnosis of tuberculosis.

The second case (TT-85-2-51) was that of an adult vertebral column with extensive destruction and fusion of several vertebral bodies (Fig. 1c). On cross-section, there was intra-osseous lytic destruction with several fistulae, strongly suggesting chronic suppurative inflammation caused by tuberculosis (Fig. 1d). No other skeletal components could be identified in this case.

The third case in this group (DAN 33-K93.11) comprised a thoraco-lumbar vertebra of an adult individual presenting with fusion of the vertebral bodies of T12 and L1 and collapse of the anterior part of the vertebral bodies, thereby leading to significant gibbus formation. On cross-section this sample also showed osteolytic destruction, but no abscess or fistula formation. As no other skeletal elements could be identified, no data on the age and sex of the affected individual were available.

Probable cases of skeletal TB. This group contained 17 samples showing various pathological bone alterations, but without the typical features of tuberculosis. These cases had the following specific features.

In 11 cases from the Theban material (TT-84-4, TT-852-21, TT-95-41, TT-183-29, TT196-M163; TT-453-15, DAN 0-93.11, DAN 31-94-1, DAN 46-95.1, DAN 10694.1 and DAN M7-93.11), as well as two of the bone samples from Abydos (U 559; Q-W5), parts of the vertebral column showed pathological alterations; however, these were not specific for tuberculous spondylitis. They comprised focal destruction of isolated vertebral bodies, pitting of the periosteal surface, anterior or posterior fusion of vertebrae, or both, or spondylophytic lipping with partial fusion of vertebral bodies that were suggestive of spondylosis or diffuse idiopathic skeletal hyperostosis (DISH) (Fig 2). Three further cases showed periosteal bone reaction of ribs (TT-95-28, TT-95-35 and TT-95-164) or the clavicle 

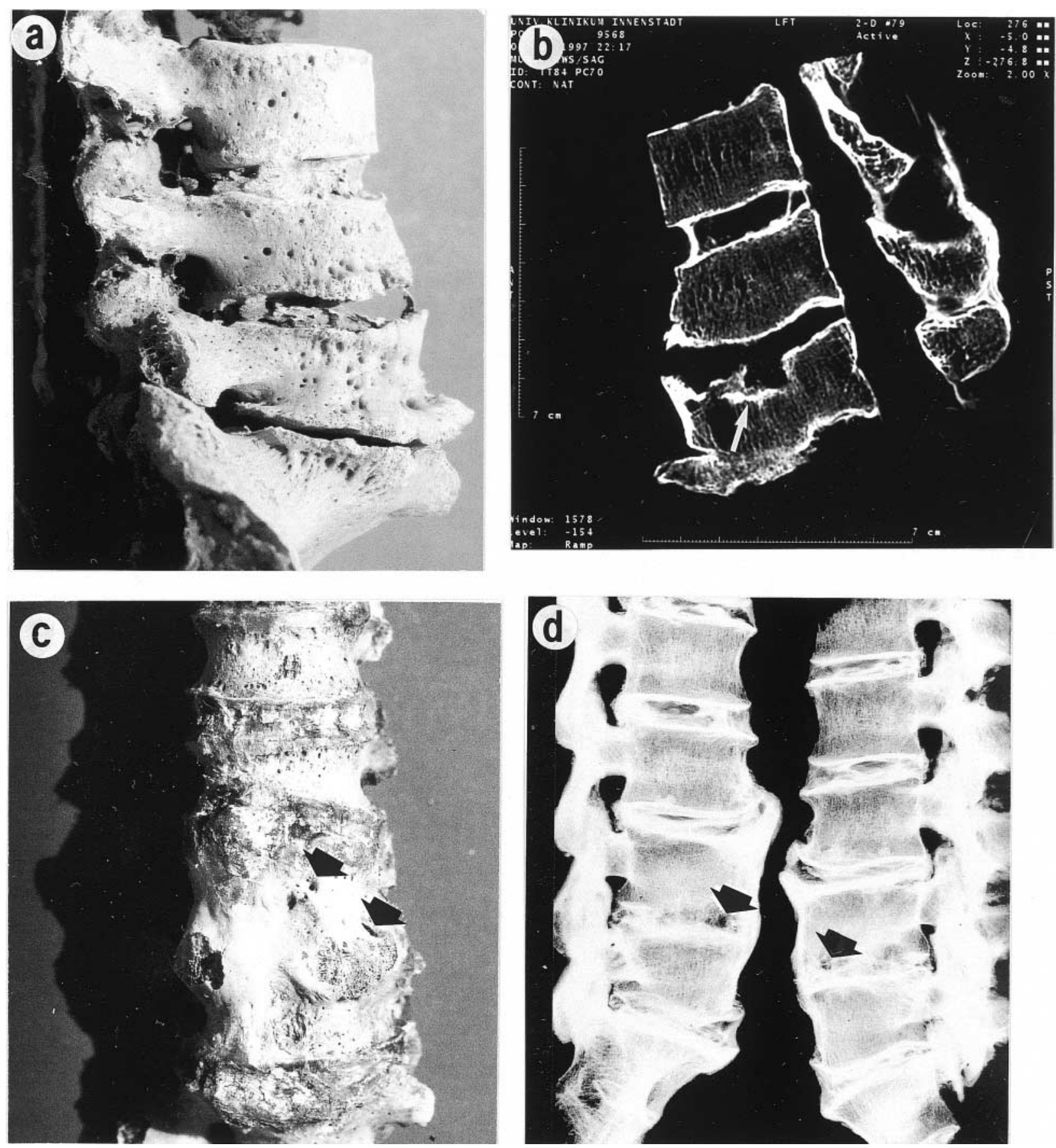

Fig. 1. Macromorphological and radiological findings in ancient Egyptian mummies with typical signs of tuberculous spondylitis (a) Case TT-84-70: the two lowest vertebral bodies are severely damaged with ventral lipping and loss of vertebral body height. (b) On CT scans, a significant osteolytic destruction within the affected vertebral bodies with osteosclerotic margins (arrow) are seen. (c) Case TT-85-2-51: the lumbar vertebra is completely fused; on the surface several fistular defects (arrow) are seen perforating the cortical bone. (d) On radiograms of longitudinal sections through this vertebra, extensive intraosseous lytic destructions with fistular defects (arrows) are observed.

(TT-95-34), suggesting an inflammatory reaction (Fig. 2e). Detailed data are given in Table 1.

Specimens without morphological evidence of tuberculosis. As well as samples with evidence for inflammatory bone reaction, the study analysed morphologically unremarkable bone samples, which were obtained from the same burial sites. This material was obtained from 7 lumbar and thoracic vertebrae, 10 temporal bones, 2 samples from skulls and 2 samples from tarsal bones. These samples could be attributed to individuals different to those with either typical or non-typical bone alterations described before, as this material came from burials that could be clearly separated from those harbouring the TB DNA-containing samples described before. Four samples from Thebes were from tombs dated archaeologically to the period of the Middle Kingdom (c. 2050-1650 BC), 15 further samples from 

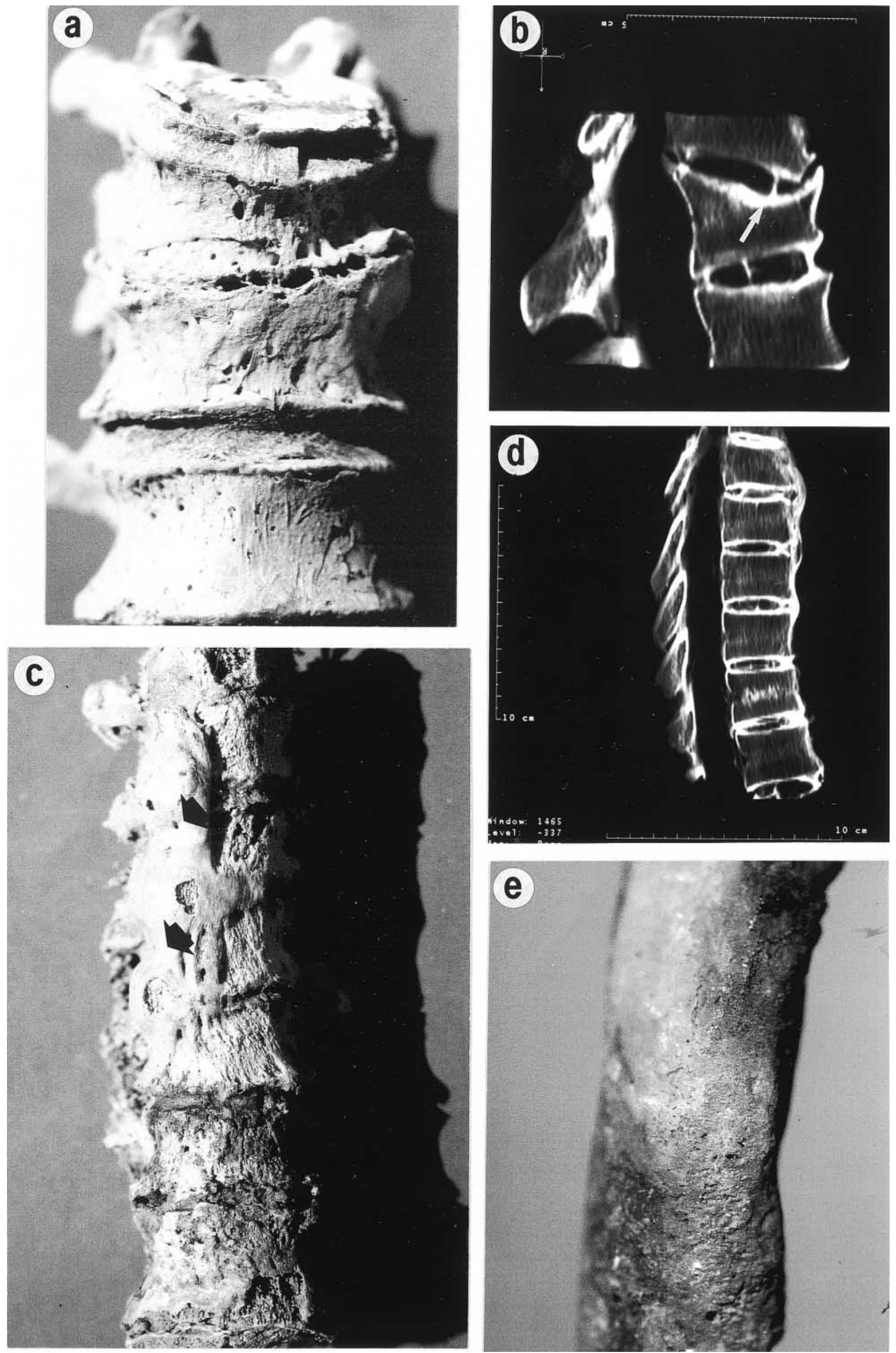
Thebes were from New Kingdom tombs (c. 1550$1080 \mathrm{BC}$ ) and the two cases from Abydos were from early dynastic tombs (c. 3050-2650 BC). A detailed description is presented in Table 2 .

\section{Molecular findings}

Amplification of human $\beta$-actin DNA. To test for the absence of PCR inhibitors and the existence of amplifiable DNA in the extracted samples, a 202-bp fragment of the human $\beta$-actin gene was first amplified from all samples. Human $\beta$-actin DNA could be isolated and amplified in 27 of the 41 cases (63.4\%). No human $\beta$-actin DNA was detected in five cases where non-specific bone lesions were seen and in nine samples from unremarkable bones (Fig. 3).

Amplification of amelogenin and SRY DNA. To rule out possible contamination of the material, the gender of the subject was identified by testing the samples for the presence of both the amelogenin gene and the SRY gene. This test provided a positive molecular result in $18(43.9 \%)$ of the 41 cases, whereby a molecular sex typing was successful by analysis of amelogenin in 17 cases (Fig. 4a) and 1 further case was identified by the SRY result (Fig. 4b). In general, the rate of SRYpositive samples (indicating males) was lower (35.3\%) than for the male pattern of the amelogenin gene $(58.8 \%)$. It was possible to identify $58.8 \%$ males and $42.2 \%$ females by this approach (see Table 3 ).

A comparison between the molecular and the anthropological sex typing was possible in 10 cases (Table 3 ). A concordance between both approaches was seen in 9 of those 10 cases. When taking the SRY gene expression into consideration, all four male individuals with anthropological and molecular sex identification gave the same result. In one individual (DAN C-93.11) the anthropological investigation of fragments of the skull had suggested a male individual; however, the DNA test for the amelogenin gene provided clear evidence of a female.

Amplification and identification of mycobacterial $D N A$. In a further step, the study applied a primer set that specifically detects the insertion sequence IS6110 [17] indicating the presence of mycobacteria of the $M$. tuberculosis complex (M. tuberculosis, $M$. bovis, M. microti, M. africanum and M. simiae) causing tuberculosis. Of all the cases analysed, nine were unambiguously positive for mycobacterial DNA of the M. tuberculosis complex (Fig. 5). The blank controls were constantly negative. To confirm these data, in several cases the specificity of the PCR was confirmed by digestion with the restriction enzyme Hae III [19]. This reaction revealed a typical cleavage of the PCR product in a 94-bp and in a 29-bp fragment as expected (Fig. 5b). Furthermore, direct sequencing of amplified DNA of the IS6110 insertion sequence was performed in several cases. This reaction provided a sequence confirming the presence of DNA of M. tuberculosis (Fig. 6).

Of the 30 cases with amplifiable DNA, 9 cases (30\%) were identified as tuberculosis-positive (Tables 1 and 2). When the three morphological groups were analysed separately, a specific reaction of M. tuberculosis was observed in two of the three cases of typical tuberculous spondylitis. One case (DAN-93.11-33) remained negative despite repeated tests. Of the group with non-specific alterations, four cases had to be excluded from further analysis, as they did not contain amplifiable DNA (either $\beta$-actin or amelogenin). Of the remaining 13 cases, 5 could be identified as $M$. tuberculosis-positive (38.5\%). Most interestingly, two cases were from the necropolis of Abydos dating back to the first dynasty (early dynastic period, c. 3000 BC). Therefore, these $M$. tuberculosis-positive cases are nearly $1000-1500$ years older than those obtained from

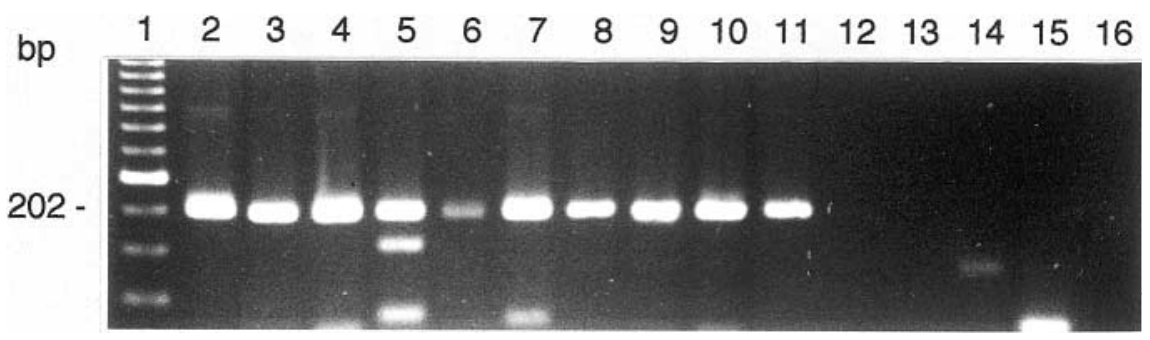

Fig. 3. Amplification of the human $\beta$-actin gene in ancient skeletal material. Lane 1, 50-bp standard ladder; 2-13; amplification products of selected bone samples; 14-16, blank controls.

Fig. 2. Morphological findings in probable, but not specific cases of osseous tuberculosis. (a) Case DAN 46-95.1: an almost selective ventral destruction of the lowest thoracic vertebral body. (b) On CT scan, apart from bony sclerosis (arrow), no typical intraosseous osteolytic defect is seen, so that the reason for the defect remains uncertain. (c) Case TT-453-15: the vertebral changes of major superficial, partly bridging bony sclerosis suggest (arrows) much more diffuse idiopathic skeletal hyperostosis (DISH) than inflammatory bone reaction. (d) CT scans showing that there is no significant intraosseous destruction visible. (e) Besides vertebral alterations, isolated cases with periostitis (ribs, clavicle) suggest - such as in case TT-95-35 - inflammatory changes, probably arising from tuberculosis. 

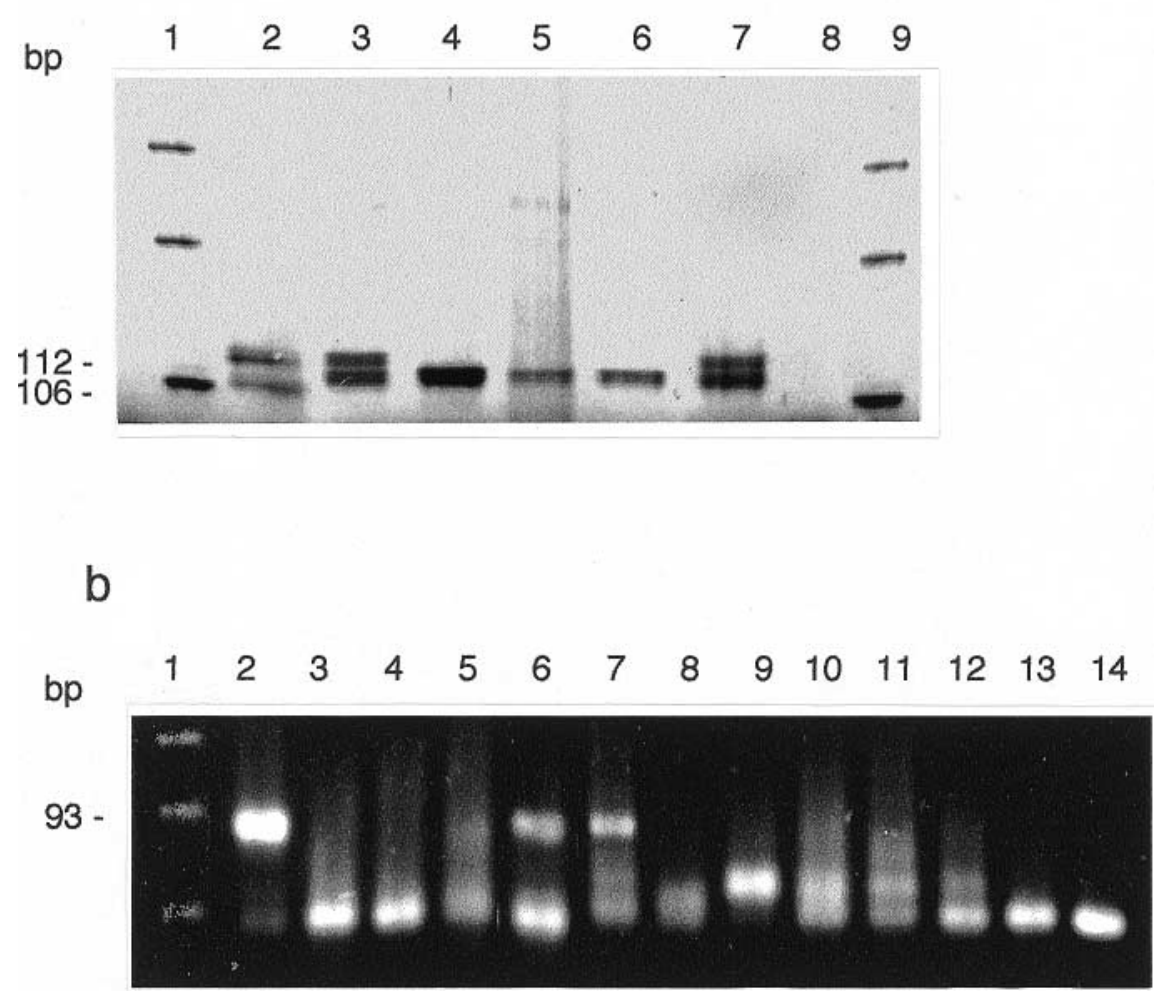

Fig. 4. Molecular sex determination of the ancient skeletal material. (a) Amplification of the amelogenin gene. Lanes 1 and 9, 100-bp standard ladder; 2-7, amplification products of selected bone samples; 8, blank control. (b) Amplification of the SRY gene. Lane 1, 50-bp standard ladder; 2-11, amplification products of selected bone samples; 12-14, blank controls.

the Theban necropolis. In the third group, 14 cases contained amplifiable DNA as evidenced by the presence of $\beta$-actin or amelogenin. Surprisingly, two of those 14 cases were unambiguously positive for $M$. tuberculosis DNA on repeated analyses (14.3\%).

\section{Discussion}

This study analysed a series of bone samples from an ancient Egyptian population to detect the presence of mycobacterial DNA by PCR amplification. The material was mainly taken from the human remains of the socalled 'tombs of the nobles', from the necropolis of Thebes-West, which represents the cemetery of a socially upper class population during the 'Middle Kingdom' (2100-1800 BC) and 'New Kingdom' (1550-1080 BC) and subsequent periods. This era has been reported to be one of the most prosperous times in ancient Egyptian history and at that time Thebes was the capital of the ancient Egyptian Empire. Therefore, it is widely accepted that during that time living conditions were good. Thebes is assumed to have been a large city of an estimated population of several 10000. Dense crowding of people, likely to have occurred in the Theban city, may have been a significant factor for the manifestation and spread of infectious diseases in that population.

Besides this material from Thebes, the study had access to a small number of specimens from a significantly older Egyptian necropolis, at Abydos, which was used since early dynastic times (c. $3000 \mathrm{BC}$ ) by socially upper class people in the close vicinity of the pharaoh. Thus it was possible to include two samples of suspicious vertebral bones presenting with lumbar osteolysis, as well as two further unremarkable vertebral bones from Abydos in the study.

Previous work by several authors indicates that ancient DNA may be recovered from Egyptian material in sufficient quantity and quality that genetic material from pathogenic organisms may be identified unambiguously. In general, this approach has been used for the detection of tuberculosis [1-10], and also for the identification of other pathogens, such as M. leprae [22, 23], Plasmodium falciparum [24], Trypanosoma cruzi [25], Yersinia pestis [26] and Escherichia coli [27]. Previous studies had shown that this approach is applicable to ancient Egyptian material, as $M$. tuberculosis was identified in one of the mummies investigated [5]. The presence of M. tuberculosis DNA in Egyptian material has also been confirmed recently 


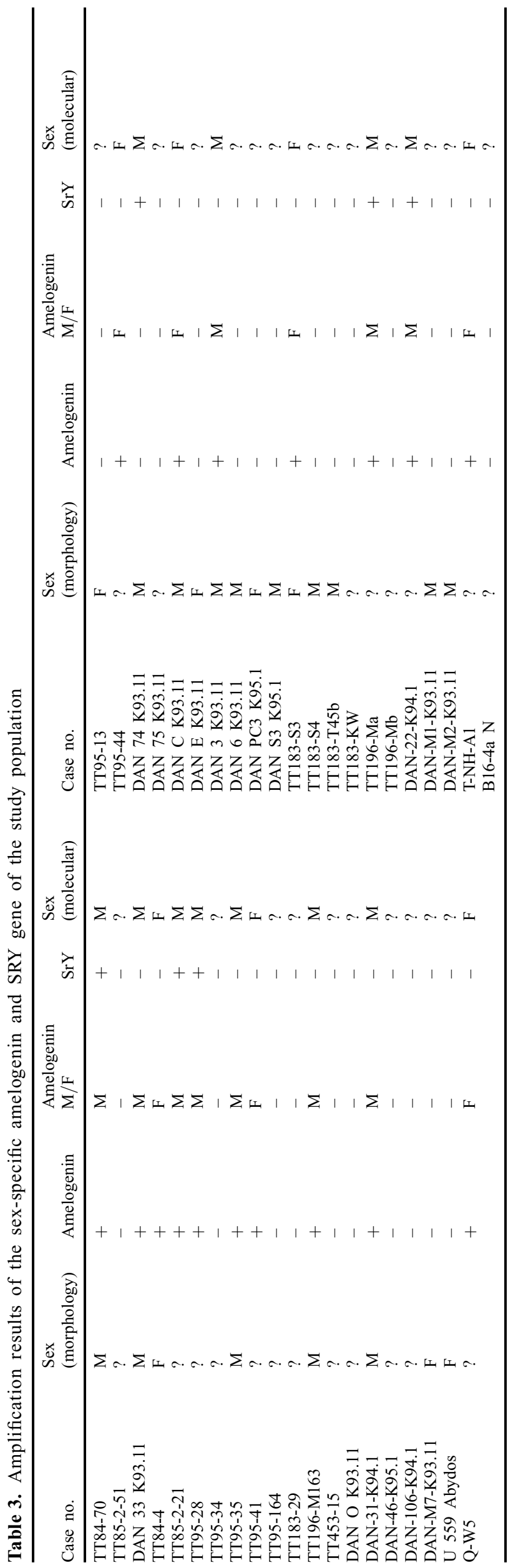

by Crubezy and co-workers in a 5400-year-old predynastic skeleton [8].

The present study aimed to measure the frequency of the presence mycobacterial DNA in various settings of pathological and normal bone samples. This may allow an estimate of the incidence of tuberculosis in that ancient population and, thus, may provide insight into the epidemiology of that disease in historic times.

Ancient DNA was extracted from 30 of the 41 cases under investigation, as evidenced by amplification of the $\beta$-actin and the amelogenin gene, thereby confirming that ancient DNA may be recovered from the majority of ancient Egyptian samples.

Three of the cases in the present study showed typical macromorphological evidence of osseous tuberculosis, whereas 17 cases provided much less specific morphological alterations, which may also have been caused by a tuberculous infection. As it is known that several pathological conditions other than tuberculosis - such as traumatic alterations or infections [28, 29] - may result in similar bone abnormalities, only the detection of specific mycobacterial DNA provides the definitive diagnosis. Molecular studies with PCR assays can clearly prove the presence of mycobacterial DNA, thus confirming the morphological diagnosis. However, this approach requires certain experimental conditions to avoid pitfalls. Primarily, these comprise methods to prevent contamination with recent microbial DNA, the inhibition of $\mathrm{Taq}$ polymerase during PCR and the amplification of non-specific products. To solve these problems, in the present study the sample surface was carefully decontaminated by chemical cleaning with DNA-degrading sodium hypochlorite as well as by mechanical removal of the outer layers of the bones. Numerous blank controls without any DNA were always processed in parallel. Independent DNA extractions were performed on at least two different specimens from the same samples. Several samples were analysed separately by two distant laboratories (Munich and Regensburg), and lastly, the resulting data were blinded before cross-checking.

As a further attempt to exclude contamination the gender of the study population was analysed by parallel molecular methods. The rate of successful amplicons for the amelogenin and the SRY gene was somewhat lower than for the human $\beta$-actin gene. This is not surprising, as $\beta$-actin is a multicopy gene in man [30]. A very high rate of concordance between the anthropological and the molecular approach was observed; in 9 in the sex typing of 10 cases with sufficient data provided the same sex. One case that had been classified as a male on the grounds of anthropological inspections of the fragmented skull turned out to be a female in the molecular analysis. Taken together, these data excluded the possibility of contamination of those samples by modern genomic DNA, as the excavation 


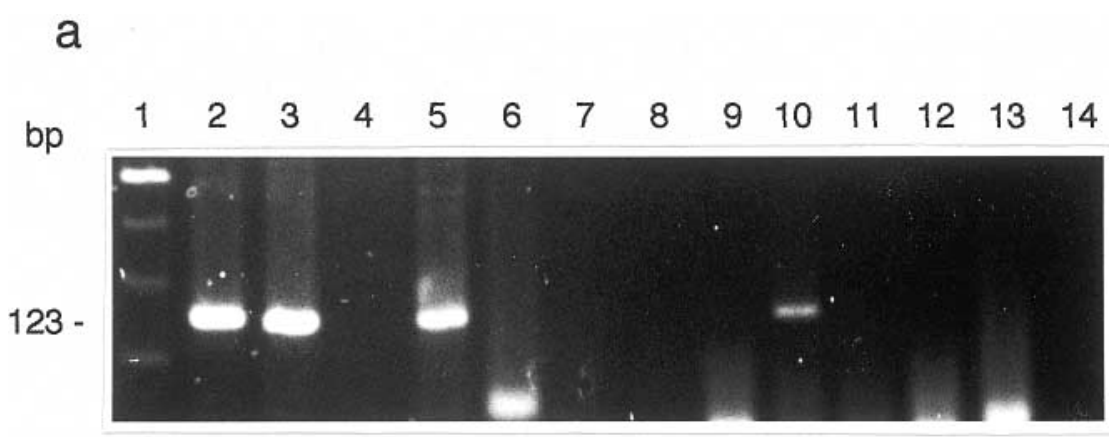

b

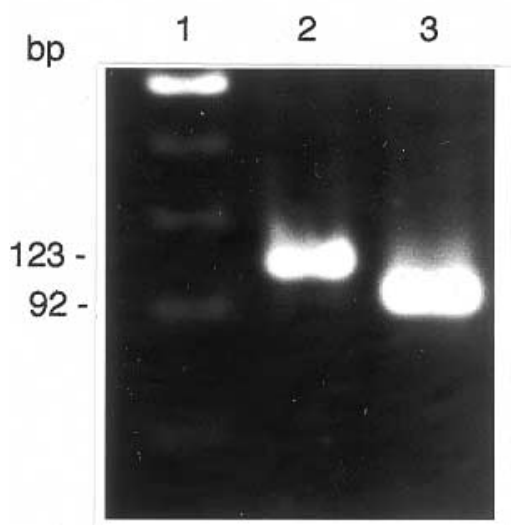

Fig. 5. PCR products for M. tuberculosis DNA (IS6110) in the ancient Egyptian skeletal material. (a) Amplification products of selected cases. Lane 1, 50-bp standard ladder; 2-11, amplification products of selected cases; 12-14, blank controls. (b) Example of Hae III enzyme digestion in one case with IS6110-positive reaction. Lane 1, 50-bp standard ladder; 2, before and lane $\mathbf{3}$, following Hae III-digestion with the reaction products of the expected size.

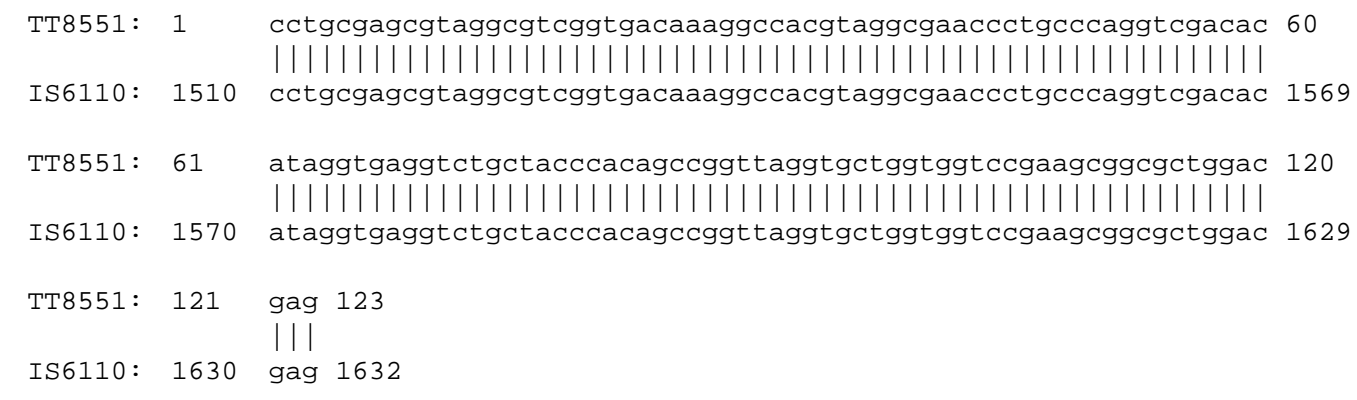

Fig. 6. Example of the sequence data obtained for the IS6110 sequence (case TT-85-2-51).

crew in Egypt and the team performing the molecular DNA tests in Munich, Germany, were all males. In contrast, in the second collaborative laboratory (Regensburg) the analysis of the extracted ancient DNA was performed only by women, but the cases tested there demonstrated the same results as in the Munich laboratory.

This study used a primer set that specifically recognises the repetitive insertion sequence IS6110 which covers the M. tuberculosis complex, i.e., the genome of M. tuberculosis, M. bovis, M. microti, M. africanum and $M$. simiae [17]. The specificity of the amplified segments was further confirmed by restriction endonuclease digestion for IS6110 [21] and by direct sequencing of the PCR products. The specificity of this gene sequence for the M. tuberculosis complex has been questioned recently. Although the amplification of the complete insertion sequence IS6110 may result in a false-positive result, several contemporary studies have shown that, in particular, the amplification of the 123-bp fragment used in the present study provided results specific for the M. tuberculosis complex [31,32]. A further study on archival bone specimens of $c .100$ years of age also provided a specific positive amplification product with this sequence only for the M. tuberculosis complex, but not for other mycobacteria (particularly ubiquitous soil mycobacteria), such as $M$. gordonae or M. aurum [4]. 
In the three cases with typical morphological features of tuberculosis in the study series, only two cases with molecularly confirmed tuberculosis were observed. This underlines the limitation of ancient DNA investigations, which is primarily dependent on the preservation of the target DNA. This in turn is influenced by several factors such as soil conditions, temperature, and humidity. This confirms the idea that negative results do not necessarily rule out an infection with $M$. tuberculosis and has led to the opinion that PCR can be used only to confirm a diagnosis [29]. In contrast, observations in the present study clearly demonstrate the capability of diagnosing non-specific bone pathology by molecular techniques. Molecular biology represents an important extension of the diagnostic spectrum and may help to identify new criteria for differential diagnosis. However, the results also clearly indicate that combining macromorphological and molecular techniques substantially improves the diagnostic reliability and, therefore, should be used whenever possible.

Besides the two molecularly proven cases with tuberculosis and typical macromorphology, a positive DNA reaction was also found in c. $40 \%$ of specimens with non-specific bone changes and - even more interestingly - in c. $15 \%$ of completely unremarkable bones. Thus, two cases with unremarkable skull bones were found to contain mycobacterial DNA. Unfortunately, there are no data available about any possible pathological alterations of the vertebral bodies of those TB-positive skull samples, and therefore it is possible that those individuals may have had tuberculous osseous changes in other skeletal regions. Futhermore, none of the normal vertebral bodies gave a positive result for mycobacterial DNA. This high frequency of DNA-positive cases without morphological alterations is difficult to interpret. It remains uncertain whether those people suffered from clinical tuberculosis. However, it is conceivable that in those cases a systemic spread of the bacteria immediately before death may have led to the deposition of M. tuberculosis DNA in the bone tissue. In this instance, it may be assumed that those individuals also suffered from organ tuberculosis with bacteriaemia. However, it is possible that minor bacteriaemic spread of $M$. tuberculosis may have occurred without 'clinically' relevant organ manifestation. Nevertheless, this observation strongly suggests contact between individuals and the bacteria.

Currently, c. $3 \%$ of cases with pulmonary tuberculosis manifest with osseous involvement of the disease [11]. However, it is assumed that the lack of early diagnosis and chemotherapeutic intervention may have led to a higher rate of osseous tuberculosis. Likewise, it has been suggested that in previous populations $c .10 \%$ of tuberculosis patients suffered from bone infection. Although the population analysed in this study is quite small and contains a disproportionate number of cases with pathological spinal abnormalities, tuberculosis may have been common in the ancient Egyptian populations investigated, at least significantly higher than suggested previously by other authors [33]. It is interesting that a relatively low life expectancy in the Theban population was described recently [34]. This reduced life expectancy may have resulted from a considerable proportion from chronic infection by various pathogenic organisms, such as tuberculosis and parasitosis. Both conditions have been documented in ancient Egypt $[35,36]$. Although the present study provides evidence that tuberculosis may indeed have contributed considerably to this poor life expectancy, further studies on other ancient Egyptian populations are necessary to substantiate this hypothesis.

The study was supported by a grant from the Deutsche Forschungsgemeinshaft (NE575/3-3).

\section{References}

1. Spigelman M, Lemma E. The use of polymerase chain reaction to detect Mycobacterium tuberculosis in ancient skeletons. Int J Osteoarchaeol 1993; 3: 137-143.

2. Salo WL, Aufderheide AC, Buikstra J, Holcomb TA. Identification of Mycobacterium tuberculosis DNA in a preColumbian Peruvian mummy. Proc Natl Acad Sci USA 1994; 91: 2091-2094.

3. Taylor GM, Crossey M, Saldanha J, Waldron T. DNA from Mycobacterium tuberculosis identified in mediaeval human skeletal remains using polymerase chain reaction. J Archaeol Sci 1996; 23: 789-798.

4. Baron H, Hummel S, Herrmann B. Mycobacterium tuberculosis complex DNA in ancient human bones. J Archaeol Sci 1996; 23: 667-671.

5. Nerlich AG, Haas CJ, Zink A, Szeimies U, Hagedorn HG. Molecular evidence for tuberculosis in an Egyptian mummy. Lancet 1997; 350: 1404.

6. Faerman M, Jankauskas R, Gorski A, Bercovier H, Greenblatt CL. Prevalence of human tuberculosis in a medieval population of Lithuania studied by ancient DNA analysis. Ancient Biomolecules 1997; 1: 205-214.

7. Donoghue HD, Spigelman M, Zias J, Gernaey-Child AM, Minnikin DE. Mycobacterium tuberculosis complex DNA in calcified pleura from remains 1400 years old. Lett Appl Microbiol 1998; 27: 265-269.

8. Crubézy É, Ludes B, Poveda J-D, Clayton J, Crouau-Roy B, Montagnon D. Identification of Mycobacterium DNA in an Egyptian Pott's disease of 5,400 years old. C R Acad Sci III 1998; 321: 941-951.

9. Zink A, Haas CJ, Hagedorn H, Szeimies U, Nerlich A. Morphological and molecular evidence for pulmonary and osseous tuberculosis in a mummy from ancient Egypt. In: Pálfi GY, Dutour O, Deák J, Hutás I (eds) Tuberculosis: past and present. Budapest-Szeged, Golden Book - TB Foundation. 1999: 379-382.

10. Haas CJ, Zink A, Molnár E et al. Molecular evidence for tuberculosis in Hungarian tissue samples. In: Pálfi GY, Dutour O, Deák J, Hutás I (eds) Tuberculosis: past and present. Budapest-Szeged, Golden Book - TB Foundation. 1999: 385-391.

11. McTammany JR, Moser KM, Houk VN. Disseminated bone tuberculosis. Review of the literature and presentation of an unusual case. Am Rev Respir Dis 1963; 87: 889-895.

12. Nerlich A, Reischl U, Haas C, Wolf H, Zink A. Identification and gene analysis of Mycobacterium tuberculosis in tissue samples from ancient Egyptian mummies. Biol Chem 1998; 379 Special Suppl: S106.

13. Ortner DJ. Putschar WGJ. Identification of pathological conditions in human skeletal remains. (Smithsonian contributions to anthropology no. 28) Washington, Smithsonian Institution Press. 1981.

14. Resnick D, Niwayama G. Diagnosis of bone and joint disorders, 2nd edn. Philadelphia, Saunders. 1988. 
15. Broom R, Sol CJA, Salimans MMM, Jansen CL, Wertheim-van Dillen PME, van der Noordaa J. Rapid and simple method for purification of nucleic acids. $J$ Clin Microbiol 1990; 28: 495-503.

16. Evison MP, Smilie DM, Chamberlain AT. Extraction of singlecopy nuclear DNA from forensic specimens with a variety of postmortem histories. J Forensic Sci 1997; 42: 1032-1038.

17. Eisenach KD, Cave MD, Bates JH, Crawford JT. Polymerase chain reaction amplification of a repetitive DNA sequence specific for Mycobacterium tuberculosis. J Infect Dis 1990; 161: $977-981$.

18. Ghossein RA, Ross DG, Salomon RN, Rabson AR. A search for mycobacterial DNA in saucoidosis using the polymerase chain reaction. Am J Clin Pathol 1994; 101: 733-737.

19. Santos FR, Pandya A, Tyler-Smith C. Reliability of DNAbased sex tests. Nat Genet 1998; 18: 103.

20. Nakahori Y, Takenaka O, Nakagome Y. A human X-Y homologous region encodes "Amelogenin". Genomics 1991; 9: $264-269$.

21. Bohle RM, Heidemann A, Borkhardt A, Velcovsky H-G, Altmannsberger H-M. [Detection of mycobacterial DNA from paraffin-embedded tissue in lung and lymphoid epithelioid granulomas.] Verh Dtsch Ges Pathol 1994; 78: 189-194.

22. Rafi A, Spigelman M, Stanford J et al. DNA of Mycobacterium leprae detected in ancient bone. Int J Osteoarchaeol 1994; 4: $287-290$.

23. Haas CJ, Zink A, Pálfi GY, Szeimies U, Nerlich AG. Detection of leprosy in ancient human skeletal remains by molecular identification of Mycobacterium leprae. Am J Clin Pathol 2000; 114: 428-436.

24. Taylor GM, Rutland P, Molleson T. A sensitive polymerase chain reaction method for the detection of Plasmodium species DNA in ancient human remains. Ancient Biomolecules 1997; 1: $193-203$.

25. Guhl F, Jaramillo C, Vallejo GA et al. Isolation of Trypanosoma cruzi DNA in 4,000-year-old mummified human tissue from Northern Chile. Am J Phys Anthropol 1999; 108: 401-407.

26. Drancourt M, Aboudharam G, Signoli M, Dutour O, Raoult D. Detection of 400-year-old Yersinia pestis DNA in human dental pulp: an approach to the diagnosis of ancient septicemia. Proc Natl Acad Sci USA 1998; 95: 1263712640.

27. Fricker EJ, Spigelman M, Fricker CR. The detection of Escherichia coli DNA in the ancient remains of Lindow Man using the polymerase chain reaction. Lett Appl Microbiol 1997; 24: $351-354$.

28. Capasso L. Brucellosis at Herculaneum (79AD). Int $J$ Osteoarchaeol 1999; 9: 277-288.

29. Waldron T. The palaeoepidemiology of tuberculosis: some problems considered. In: Pálfi GY, Dutour O, Deák J, Hutás I (eds) Tuberculosis: past and present. Budapest-Szeged, Golden Book - TB Foundation. 1999: 471-478.

30. Ponte P, Gunning P, Blau H, Kedes L. Human actin genes are single copy for alpha-skeletal and alpha-cardiac actin but multicopy for beta- and gamma-cytoskeletal genes: 3 ' untranslated regions are isotype specific but are conserved in evolution. Mol Cell Biol 1983; 3: 1783-1791.

31. Hellyer TJ, DesJardin LE, Assaf MK, Bates JH, Cave MD, Eisenach KD. Specificity of IS6110-based amplification assays for Mycobacterium tuberculosis complex. J Clin Microbiol 1996; 34: 2843-2846.

32. Marchetti G, Gori A, Catozzi L et al. Evaluation of PCR in detection of Mycobacterium tuberculosis from formalin-fixed, paraffin-embedded tissues: comparison of four amplification assays. J Clin Microbiol 1998; 36: 1512-1517.

33. Strouhal E. Ancient Egypt and tuberculosis. In: Pálfi GY, Dutour O, Deák J, Hutás I (eds) Tuberculosis: past and present. Budapest-Szeged, Golden Book - TB Foundation. 1999: $453-460$.

34. Nerlich AG, Zink A, Hagedorn H, Szeimies U, Weyss C. Anthropological and paleopathological analysis of the human remains from three "tombs of the nobles" of the necropolis of Thebes-West, Upper Egypt. Anthropol Anz (in press).

35. Ruffer MA. Note on the presence of "Bilharzia haematobia" in Egyptian mummies of the twentieth dynasty (1250$1000 \mathrm{BC}) \mathrm{Br}$ Med $J$ 1910; 1: 16

36. Nerlich AG, Parsche F, Wiest I, Schramel P, Löhrs U. Extensive pulmonary haemorrhage in an Egyptian mummy. Virchows Arch 1995; 427: 423-429. 